Unexpected Encounters with Deep Time Enchantment. Bog Bodies, Crannogs and 'Otherworldly' sites. The materializing powers of disjunctures in time

\section{Deep time}

The concept of 'deep time' is rooted in challenges to officially sanctioned biblical narratives. Bishop James Ussher's edict that the earth was created in 4004 BC was challenged by James Hutton's observations on the deep stratigraphy evident in the exposed strata of Scottish sea-cliffs (McPhee 1981, 20). These observations led him to propose that the planet was much older. In fact it is 4.5 billion years old, whereas the span of humanity within this long-term history of the earth is relatively short, making it hard to grasp our place within this geological 'deep time' (McPhee 1981, 20). Chakrabarty $(2009,213-20)$ thus argues that in order to better understand both our situated position and responsibilities within the contemporary world with its climate and environmental problems, there is a great need to question the barriers between histories of geological deep time natural history and that of the human. This will have major implications for how history is studied and comprehended. Such a union has the capacity to query what a world without humanity might be like, and analysing the important boundary of the 'Anthropocene', where (following the Holocene) human beings are understood to have crossed the nature:culture boundary to become one of the main actors in global geological change (Crutzen and Stoermer 2000). The present can then be understood as a key period, whereby the transformation of the earth is happening at such an accelerated rate (Steffen et al. 2015) that it could threaten the life conditions for many species on the planet.

The important relationship between history and natural science has been firmly acknowledged in the current era of major climate and environmental challenges. Yet how that relationship is actually nurtured and worked out is often more uncertain. Edgeworth (2014) has argued for archaeology's central role in evidencing anthropogenic impact, and thus achieving a well-founded evaluation of what we might call the 'Anthropocene predicament'. This is not simply a matter of constructing long-term models of palaeo-environmental change, as important as that might be. Nor is this merely the potential for archaeological material to stand alongside other strands of noncultural evidence, revealing long-term chains of cause and effect, against which different hypotheses and models can be tested. More fundamentally, the subject has the potential to contribute to the wider debate on environmental humanities (Rose et al. 2012) through its dealings with memory and time, but also with 'archaeological' deep-time materialization processes. Here the research of Lucas (2015) and Olivier (2011) is of particular interest. For example, archaeology's grasp of the complex ways in which agency emerges in admixtures of humans and non-humans (comp. Haraway 2008), and the specific form that different 'assemblages' or 'entanglements' of actors and resources take in space-time, create the possibility of seeing other ways of being in the world - in Haraway's (2008) terms 'autre-mondialisation' or 'other worlding'. Archaeology has the power to disrupt notions of inevitability or neo-social evolutionism: to reveal alternative assemblages, arrangements and relationships. Not only can it contribute in a subtle and historically informed way to 'place-making' within the world, but it could be deployed to speak to contemporary issues of inter-generational responsibilities (between generations), debates on 'global'

justice (in terms of historical inequalities), and our ethics towards, and care for, the human and more-than-human world.

Curiously, when deep time and material formation processes came to the fore in discussions about climate and environmental change, social constructivist heritage research tended to argue that heritage should be understood as a non-material, short-term phenomenon with a to argue mainly in the present In Smith's $(2006,3)$ Uses of the Past (see also Smith 2014, and alternative mainly approches in Harison 2013 ) is produced and valued mainly according to current political and economic concerns) can be regarded as a form of presentism (cf. Eriksen 2014, 158-59). This rather exclusive focus on meaning in the present is compounded by another problem. As has been argued by Solli $(2011,43-47)$, the social constructivist/linguistic turn in heritage studies unfortunately under-articulates the interrelationship between human- and thing-agency, which may be particularly damaging in the age of the Anthropocene. While discourse analysis in heritage studies (as used by Smith 2006) is renowned for its ability to foreground both ethical issues and injustices in the biases 006 ) is in 'Authorised Heritage Discourse', it deals less well with the workings of deep time observed in 'Authorised Heritage Discourse', it deals less well processes. Recent work in archaeology, such as Jones (2010), Lucas (2015), Joy (2015), Fredengren (2015) and Fowler and Hartis (2015), has tried to reconct the fact that archaeological materials on the one hand imply deeptime materialsation processes, but at the same time are contemporary phenomena. They advocate a relational approach which could also be useful for modifying the presentism which is problematically foregrounded in social constructivist heritage studies, making use of new materialist feminist theories such as those of Barad $(2007,2010)$. Consequently, this paper deals with how deep-time matter 'matters' and how encounters with archaeological deeptime materials, in the past and in the present, can be powerfully affective. Deep time and history $\mathrm{h}$ also been important in discussion of environmental engagement, spirituality and religion (White 1967, Berry 1988, Northcott 2015), and this paper deals in particular with the interface between these aspects. It will show how meetings with materialities from the past may have given rise to religious effects (as in experiences of the otherworld, in enchantments, hierophanies or hauntings) and how such material engagements, through emotional and materializing effects, can play a role i forming relationships with 'naturecultures' (comp. Haraway 2008) and thereby inform modern ecological ethics. Its aim is to throw some light on how deep-time materialities intrude on the contemporary (both in past and present) and how a revised concept of heritage could embrace this as a powerful way to problematize boundaries (nature:culture, past:present:future) to more powerful ethical effect, particularly in environmental action.

The case studies are used to address the following questions:

- How can meetings with deep-time archaeological material provide encounters that give rise to socalled enchantment effects?

- How could these play a role in the development of environmental ethics and issues of intergenerational care?

- How can the heritage concept be altered to allow for an understanding of heritage not only as social constructs, but also as deep-time materialising phenomena?

- How would such a move realise the potential of heritage to make a difference in the engagement with environmental ethics but also through curatorial practices, site management

and future green policy making?

The paper will deal specifically with people's relationships with water and wetland environments. The questions will be addressed with examples from my own research (Fredengren 2002, 2010) and others (e.g. Giles 2009) focusing on crannogs, bog bodies, lakes, wetlands and rivers. The case studies are selected due to the particular effects on materials rendered by waterlogging; creating an enhanced power to move people in their encounters with objects clearly 'out of their own time'. These examples are used to suggest that encounters with archaeology may give rise to near-religious or spiritual experiences - both in the past and in the present. This materia is particularly relevant it shows the intermingling of deep and shallow time, but also the merging of natural and cultural heritage. It will be argued that such encounters can create energizing enchanting effects, and thes have the potential to have the potential to become springboards for stimulating a move from ethical thinking to
action. This would suggest that archaeology has more to contribute to the Anthropocene predicament than mere facts and figures which chart trends or trajectories; instead, encounter can predicament than mere facts and figures which chart trends or trajectories, instead, encounter $c$ n construct, to an acknowledgment of heritage as an emerging onto-ethico-epistomological phenomenon, following the reasoning of Barad $(2007,2010)$. 
Barad's agential realism proposes that the world consists of ontologically inseparable intra-acting agencies that give rise to phenomena (whereas the actor-network term inter-acting specifies that separate actors exist per se). For Barad, these phenomena are material possibilities, where the ontology, epistemology and ethics congregate. Hence, 'past matter' is also a mattering with ethica ontology, epistemology and ethics congregate. Hence, 'past matter' is also a mattering with ethical consequences. This would open up new discourses on the ethical contribution of archaeology and heritage to the thith engagen th wonder, marvel, revelation) might be experienced by communities as a form of 'secular religion' (in
conversation with the writings of Latour 2013).

\section{Enchantment in archaeology and heritage practice}

Northcott (2015) argues that the mechanistic world view on matter, life and earth, provided by science and technology, hampers the way in which we address problems of sustainability. A alternative approach - which embraces both radically different possibilities of being and religious beliefs or spiritualism - might provide a better way of meeting the environmental
challenges of the present (see also Latour 2013, for his advocacy of a concept of 'secular religion'). challenges of the present (see also Latour 2013, for his advocacy of a concept of 'seculy For Max Weber (1989 [1919], 30), the ongoing intellectualisation, rationalisation and
bureaucratisation processes of the Western world were connected to, and dependent on, a loss bureaucratisation processes of the Western world were connected to, and dependent on, a less
of enchantment or Entzauberung of the world, and a retreat of religion from the public to the of enchantment or Entzauberung of the world, and a retreat of religion from the public to the private sphere. The term 'enchantment' has been used in heritage studies and archaeology to
discuss how art could exercise non-human agency and produce enchanting effects (Giles 2008), discuss how art could exercise non-human agency and produce enchanting effects (Giles 2008),
and how this might be both acknowledged and drawn upon in heritage conservation (see Byrne 2009).

In a previous study (Fredengren 2002) I examined the man-made islands in Lough Gara, Co. Sligo, Ireland, from the Mesolithic to the present day. Using Weber's (1989 [1919], 14, 30) concep of 'dis-enchantment, I proposed that the opposing effect could be achieved through archaeolog enquiry - as a way of re-enchanting the world by contributing to place-making. In that example, argued that archaeology deepened understandings of how the lake and its crannogs had become meaningful and played a role in the local community. The practice of archaeology was seen as a way of activating resistance in a world ruled by economists: it was argued that since such senses of place were not fully reducible or translatable in 'market terms' they could become sites of resistance to the commercialization of places and the past (Fredengren 2002, 298-99). I went on to suggest that to compress heritage places into commodities (captured as marketable heritage values) underestimates the workings of a number of complex associations. 'Doing' archaeology created a means of expanding these links through a deeper understanding of the context and meanings of a place. This challenge the dominance of economic models which struggle to handle complexity, particularly in terms of dealing with long-term cause and effect, and thus has problems with the distribution of resources and liabilities between generations as well as in engaging with issues of commonages, justices and responsibilities that extended over time (Stiglitz 2013, 366-68; Portney and Weyant 2013). The value systems of heritage are similarly presentist. As Eriksen $(2014,149-51)$ argues, the past is often understood as a property, where value is estimated from the perspective of the presentday inheritor or heir. Hence, this way of handling heritage deals less with its complex origins, materialisation processes, changes of significance and meaning or long-term consequences for future communities.

Bennett's (2001) key work entitled The Enchantment of Modern Life takes these concepts further and particularly questions the notion of a fully 'disenchanted modernity', pointing to the enduring and partic attachments to place in the word (3). To be enchanted is, for Bennett (4), 'to be struck and shaken by the ordinat that ives amid the famillar and the everyday'. Bennett $(2001,131)$ also describes and that 'enchantment is a mood of ethical potential' as it motivates not only ethical contemplation, but also ethical action. Whereas enchantment implies the 'ethical relevance of human effect', Bennett's $(2010$, xi-xii, 108) subsequent book deals more with the materials that may give rise to such enchanting effects. Whilst the study of Irish crannogs touched lightly upon these issues, the studies below develop these themes in light of Bennett's ideas.

\section{Crannogs, emotions and disjunctures in time}

The lake level of Lough Gara, located in the upper parts of the River Shannon, was artificially lowered The lake level of Lough Gara, located in the upper parts of the River Shannon, was artificially lowe
for the second time in the 1950s. This revealed not only a number of crannogs, but also large amounts of artefacts and human remains on the lake shore (Raftery 1957) (Figure 1). Forming part of a PhD project (Fredengren 2002), my research took place nearly 50 years after this event, when I collaborated with the community at Monasteraden (on the western side of the lake) on an archaeological landscape survey. The project recorded the archaeology of the lake and conducted semi-structured interviews with local people about the lake, the past and its archaeological traces and we also excavated a crannog.

Figure 1. The finding of a human skull on the newly exposed shores of Lough Gara (LIFE Magazine 26 January 1953)

The first part of the resulting publication (Fredengren 2002, 64-75) focused on local communities' relationships with the archaeological landscape, and the material connection between past and present. The title of this particular chapter, 'The past is here and there', was deliberately deployed to suggest that the past is in two places at once, as if in a betwixt and between position, thereby 'troubling' the past as a completely separate category compared to the present. As Olivier $(2011,173)$ notes, the present and the past illuminate each other and create 'time outside time', making such categorical separation of past and present redundant. Instead, archaeological material undergoes cycles of burial, discovery, preservation and decay: working as material memory (191-93) where past and present are entangled in each other in various ways. However, archaeological materials contribute to more than mere memory and meaning-making. During the interviews at Lough Gara, it became clear that for some people living in the area, the past was more actively viewed as a means of making connections. One interviewee felt that touching the stones of an old building by the lakeside would set up a link to the ancestors. This sense in which time could be collapsed through archaeological artefacts was a powerful challenge to the dominant notion of unidirectional time, and of a completely 'dead' past. Likewise, other members of the community articulated their sense of the past's agency, and continued existence and power in the present: during the excavation and survey, young adults remembered their childhood play amongst the stones of an old ruined burial ground. They became unsettled, articulating fears that they might be 'haunted' for being disrespectful to old places and ancient inhabitants. These fears were linked in complex ways to contemporary concerns about pollution and the lack of a thriving lake environment (Fredengren 2002, 70-71). Interviewees mentioned 'fish-kills' that also were reported in the news (see Humpreys 1998); events which seemed linked in their minds with their relationship to the lake's past. Overall, these interviews suggested both a folding and non-linear concept of time, as well as enduring relations which had power across time.

Earlier accounts of folklore from the lake were collected by the schoolteacher Una Staunton in 1937-1938 (St. Michael's School, Clooncunny, Co. Sligo roll number 14589, 102), and collated by the Irish Folklore Commission. Those documents present a more auspicious and spiritual vision of this real $m$, in which locals reported that 'there are castles and good people' under the lake (the 'good people' is another name for fairy-folk). According to the schoolbook manuscripts, the cause

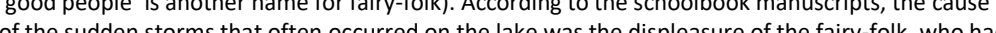
the power to stir up thad weather when they had the power to stir up bad wear lements. In the post-Enlightenmentera, attributing supernatural cause (especially emotions such 

as malice, revenge or displeasure) to such meteorological events was derided: part of a wider
discourse in which Irish identity and belief was configured through a scornful English colonial perspective (see Bourke 1999 for an in-depth account of this phenomenon). Yet for locals, whether they believed these tales literally or metaphorically, such lore provided an important store of knowled a out how to 'live right' on the land a anside its otherworlly inhabitants but also how to engage with troubled parts of the environment. Una Staunton (c. 1990 and $c$. 1986. Fron 1986, Fredengren 2002, 70), whorem, called the 'Draining of Lough Gara', which describes how the "progress' that resulted in the lowering of the lake level for drainage purposes was stalled, as it expsed 'Crannogs of the Dead'. In the poem, former generations kept vigil over the lake. The appearance of the crannogs symbolised revenge from the past, acting in the present. Once more, his sense of inter-generational relationships, crossing the 'arrow' of time, to affect the present, is palpable. Paying closer attention to the crannogs can also produce other experiences of time and place. According to Rose et al. (2012, 2), we should learn 'ho product through the environ are expanded by a range of different materialities. As I have previously argued (Fredengren 2015 and references therein), archaeology provides one of the richest disciplines through which novel materialities are revealed that can be read as indices of a variety of relationships, precisely becaus they 'trouble' the present with objects and substances that have crossed temporal boundaries. Thinking through crannogs (I suggest) is a new way of re-conceptualizing more fluid concepts of lan and water - just as other archaeologists have used studies of island communities, waterways and river traffic, or on/off-shore archaeology to foreground this same theme. Yet crannogs offer a unique perspective on this apparent dichotomy: the movement of building materials such as stone and wood, by human actors, from dry land into the water, to create these platforms, resulted in the construction of artificial land

Figure 2. Dried out cannog at Ardsoreen townland, Lough Gara, Co. Sligo, 2016 Crannogs blur the man-made and artificial boundary in a particularly powerful way. As hybrid 'natureculture' constructs, they not only reveal humans as geological and hydrological actors, they also develop their own, quite radically new materialities and environmental trajectories. Due to the way they are situated within the lake, crannogs exercise a particular material agency, where they work as guides or markers of seasonality: lake water rises in the wet winter months to conceal or flood these iconic foci, whilst the lower waters of the summers reveal and facilitate access to them. In a longer term environmental trajectory, communities used them as indices of wider change: general denaturation from extensive drainage programmes leaves them 'high and dry', laying bare the crannog on a dry shore in summer months (Figure 2). When the skirts of these islands are once more flooded, there is a sense that they have been returned to their rightful appearance (such disruptive effects of appearance and disappearance. Crannogs are designed to function as islands: but they have also become both gauges for, and indices of, 'inappropriate' change; they draw upon the past to legitimate concerns in the present. The presence of deep time in their design question current hydrological change: time is out of kilter, prompting unsettling feelings, even worry, fear.

The crannogs thus contribute to contemporary environmental debate with a material agency that stretches outside their human makers' original intentionality. They have entered into new materid relations with the lake's waters, and new meanings for its human inhabitants. Thus, to use the words of Joy $(2015,213)$, crannogs are in a slow process of 'becoming something else'. During
certain times they were active and attracted attention. They also underwent periods of decay and disappearance: as matter eroded into the waters and their remains were submerged. However, their endurance - and re-emer enquiry has enal them to enter new prosses and relationships. Ironically, lower summogical enquiry has enabled them to enter new processes and relationships. Ironically, lower summer lake for habitation phases during the Early Medieval period, C.AD 660-1000. Other crannogs, such as
Rathtinaun crannog on the eastern shore of the lake, are multiperiod sites, with layers from the Bronze and Iron Ages (c. 800-200 BC), as well as the Early Medieval period (Fredengren 2002, 111). These sites are notoriously complex to excavate as features and layers from different time periods interlace and occasionaly seem to interate interlace and occasionally seem to interact wich each other. While this could be a challenge for the time-relations in an alternative way, which could be of interest when discussing the relationship between between deep time and contemporaneity. For example, Lucas (2015) deals with how to reconcile the existence of deeper time formation processes in an archaeological "record" which at the same time are understood as cont por

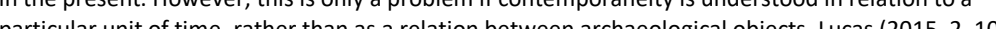
11) sular unit of time, rather than as a relation between archaeological objects. Lucas (2015, 2, 10 11) suggests an abandonment in the division of past, present and future as a set of successive features, along similar lines asOlivier (2011). Instead, Lucas suggests that contemporaneity could following Serres and Latour's (1995, 58-60) argument - be understood as points of contact, where there may be a variety of connections between materialities of different time depths. Materialities from different times percolate and infiltrate the present, while some materials have a persistence and effect for futures to come. Thus, the deep time of archaeology is not laid out in a linear way, but is better described as scrunched or folded, 'touching' in unexpected, particular or specific points. It therefore works differently to conventional chrono-linear time (see also Fredengren, forthcoming). The crannogs could, then, in a material sense, exemplify the physical folding of time: where features from different periods would become merged with each other during periods of re-use and abandonment of the site. Features dating to the Bronze Age become folded together with Early Medieval practices on some sites, for example. They show the layering of time, but the sequencing is interrupted, cut and re-started, where features, materials and practices in later periods on occasion knot with materials and practices in earlier periods. Crannogs could be seen as black holes in time, where there was no change and which people returned to over thousands of years. However, as landscape analysis has shown (Fredengren 2002, Part IV), their relations to the lake water, its surrounding landscape, humans and animals, were connected differently in the myriads of contemporaneity that were once present. Deep time 'thinking through the crannogs' could be understood as consisting of a variety of combinations of similar, but not identical, networks that interlinked through the site over time. Deep time (as well as a variety of contemporaneities) converges around the crannog sites, which act as lenses or nexus of time relations.

The crannog project (Fredengren 2002) was subsequently augmented with a landscape investigation at Lough Kinale, Co. Longford (Fredengren 2010). Whilst interviews were not utilized here, open days enabled the collection of more fleeting or anecdotal responses to the excavation of a wetland/riverside platform. The platform incorporated several layers from the Mesolithic and Neolithic periods in Derragh townland, with evidence for phases of use and abandonment, stretching over nearly 2000 years, and periods of both anthropogenic and non-cultural deposition where natural and cultural layers meshed together. The site contained habitation and knapping debris, hearths, bone, wood, peat and lake sediments. One of the interesting finds from Derragh was a well-preserved leaf that had kept its form since the Mesolithic. A trowel was used to pass the leaf directly to the hand of a visitor. The group he was with reflected that he was the first person for some 7000 years to touch this fragile trace of the past. Both diggers and visitors were visibly moved as this ephemeral object withered in his hand: many of us felt a near 'otherw were visibly moved as this ephemeral object withered in his hand: many of us felt a near 'otherworldy Mesolithic was suddenly present. It was as if the past was held for a while, allowing the creation of an intimate connection, before the act of exposure destroyed it.

In the aforementioned projects, archaeological analysis gave rise to new memories of these lakes or rivers, but encounters with ancient materials and the experience of disjunctures in deep time also stimulated emotional effects. As discussed above, experiences of past materialities can elicit feelings 
of connectivity and presence, fear/worry, anger. . .even guilt and revenge. Furthermore, the joint processes of changing lake levels and excavation of the crannogs worked to change human perceptions of seasonal change, as it visibly wrought material change to these sites and their finds. One of the key questions to ask is if the well-preserved, organic materials present on such sites - so quickly transform quickly transformed by exposure if not immediately conserved - has a particularly powerful effect exceptional preservation: the internationally renowned phenomenon of bog bodies.

\section{Bog bodies, hierophanies and holy water}

Staying within the context of Irish folklore and literature, there is good evidence to suggest that concepts of preservation and decay are intimately associated with 'being in' and 'leaving' the otherworld. One example is the medieval tale about the monastic site of Clonmacnoise, Co. Offaly, where a very curious find was made (Carey 1999). In this account, a poet heard that an

otherworlly warrior was buried at his early Christian site. The resident monks initially denied this ancient presence but when they dug a new grave within their cemetery, and accidentally found the well-preserved corpse of a 'giant' with yellow hair and a large head-wound, covered by 'blood and fresh birch leaves', they rethought their scepticism. Yet the following day the body had vanished. Carey $(1999,1-14)$ argues that this story (dealing with an otherworldly burial which is remarkably preserved), might have been used as either the source of related tales about the discovery of 'Arthur' at Glastonbury, or even an echo of the ancient classical accounts of Tacitus, of depositions of bodies in bogs, placed under wooden branches that made up hurdles. Indeed, another alternative is possible: that the monks themselves encountered or heard about the discovery of an ancient bog body in early medieval times - whose remarkable preservation was then attributed to its otherworldly being or status.

More recently, Giles (2009) proposes that the deposition of bog bodies in wetlands might have intentionally used bog pools as portals to the otherworld. Interestingly, other elements of Irish literature describe waters as places where hierophanies occur, and where the holy would emerge to become manifest in the world of the living. Such a perception of pools and bogs as places of spiritual emergence might help to explain the link observed in later prehistory between death and the deposition of human remains. Some such examples derive from the Metrical Dindshenchas, a set of Middle Irish landscape poems. One of the poems explains how Lough Cé, the lake next to Lough Gara, emerged when the druid Cé lay down and died in the middle of a green plain, and a cairn was placed over him (Gwynne 1991 [1913], 400-03). Another landscape poem (26-33) explains how Segais, an otherworldly holy well and the source of wisdom, erupted when Boánd, the wife of the king, challenged its powers. The waters chased her and her dog all the way to the sea and killed them. This act created the River Boyne that still bears Boánd's name. Hence it seems that human deaths by water, or the deposition of bodies in these contexts, was understood to draw out otherworldly and possibly also holy waters with magical efficacy into the everyday landscape.

As Giles (2009) goes on to argue, it is this peculiar effect of having stilled or stalled time that makes bog bodies such a draw for contemporary audiences, when displayed in museums. The experience of a face-to-face meeting with the dead (and rare elements of coiffured and dressed hair, intricate ornament or carefully stitched clothing) matters and appeals to visitors, in a way which is palpably different to skeletal or cremated remains. The poet Seamus Heaney (1999) has described this as the 'riddling power' of bog bodies, such as Tollund or Grauballe man: bodies that cross a variety of 'rommon-sense category boundaries - such as object:subject or man: bod culture. Yet Heaney goes further here, bringing to the fore a distinction between eye-sight and vision: the difference between simply recording or reacting to something seen, and anticipating or envisioning other ways of being in the world. Just like the crannogs, bog bodies possess a

particular vibrancy which resonates with a variety of agencies: the corpse itself, the viewer, the digger, the bog and its particular preservative powers.
Yet this powerful effect can also create tensions. In the UK in particular, these tensions have formed the focus of a debate over the ethics of display which seems particularly perturbed by the phenomenon of well-preserved human remains. Neo-pagan repatriation movements contest how archaeology treats the dead both on site and in the museum, and questions whether the dead themselves hold rights - an issue debated by both non-specialist groups and academics (see Giles 2009,80 and literature therein). In fact, as Giles (2009, 91-92) discusses, the curators of the National Museum of Ireland reflected critically upon the ethics of displaying bog bodies, placing them in alcoves which protect the bodies from direct and unintended encounters with the museum audience. The ammonite-shaped structure, external-only signage, and glowing central museum cas (one for each body) are also built to provide contemplative space, with a small bench which invites the visitor to be seated by the dead. For many people in the industrialized world, this is their first encounter with a corpse, and thus $G$ les $(2009$ ) has argued that museums play a very important role in closing the distance betwen contemporary communities and the phenomenon of death, grief and memorialisation. To 'think through bog bodies', as exemplified by both Giles and Heaney, brings out issues of care for the dead, responsibilities to past and future generations; links to the environment; and, possibly, visions for the future. Both archaeologist and poet show that their 'riddling power' has the potential to summon emotional response, to prompt contemporary reflection and thus hopefully (in the terms set out in this paper) create a notion of intergenerational care, which acts as a springboard for action.

\section{Compelling connections and enchantmen}

What these studies also show is people's strong - even compulsive - engagement with natureculture' environments where the workings of both people and their landscape intermesh in ways that cannot be wholly dis-entangled. Deep-time materialities are made present, and indeed have presences, both in past contexts and in modern times. Whilst all archaeological artefacts have this power of being 'out of time' or, rather, dragging the past into the present, a central part of this paper's argument is that well-preserved organics (as impressive as a human body, as small as a leaf) possess this peculiar 'riddling power'. The fieldwork in Lough Gara and Lough Kinale shows that meetings with the past give rise to a range of emotions, from awe and feelings of being connected, to those of hope, but possibly also feelings of horror and fear of both the past and the future. The lake and river waters also seem to have been connected with feelings of anger or at least sentience and emotional sensitivity to actions in the present. Meetings with bog bodies seem to bring about feelings of confusion, alarm, surprise, even trickery, prompting us to reconcile what can seem to be contradictory facts and categorical boundaries. They exemplify a variety of ambiguous feelings, relating to landscape (being neither land nor water), experienced both at the side of the trench and in the curated space of museums. These encounters give rise to sometimes unsettling experiences, producing precisely the kinds of effects that Bennett (2001) described as forms of enchantment. Interestingly, this fits well with Smith's (2014) argument that out of nearly 4500 visitors to museums and heritage sites, the dominant motivation for visiting exhibitions was not recreation or the acquisition of knowledge, but the desire to become 'emotionally engaged' with heritage (Smith 2014, 125-26). Acknowledging this search for a more visceral, more affecting and, potentially, more moving heritage experience is key to driving altered curatorial practices and site management. There are similarities between the experiences of enchantment as evidenced in the above case studies and those of authenticity or aura, where heritage is felt to have an 'energy field' that attracts people. However, the authenticity concept has a troubled history. Jones (2010) problematizes how the concept sits uncomfortably between traditional material approaches and primordial discourses that a pre primordial discour practices and relationships these ideas sustain'. The concept has traditionally been framed in material conservation as a natural, measurable category that strives to reach the status of a pristine 
historical original (182-83). However, that approach has been questioned by social constructivist critics, whereby authenticity has been understood more as a projection of perceived meaning in the present that can be folded around any type of material regardless of age, content or context (see Holtorf's $(2005,118)$ concept of pastness and age-value). However, Jones $(2010)$ argues that these approaches fail to explain why certain places or things become more powerful nodes of authenticity approaches fall to explain why certain places or things become more poweful nodes of authenticity than othis why this might be the case. The explanation offered by Jones $(2010)$ is that authenticity emerges through the involve their embeddedness in more extensive social networks, both now and in the past.

Jones (2010) argues that parts of the mechanism underlying people's engagement with heritage places derive from a longing for such authenticity. What is worth noting is that authenticity has taken on new meanings and significance in the modern era. Jones (2010) explains this as the result of rapid social change, whereby fewer personal inter-linkages characterize most people's lives. authenticity steps in as a surrogate for sincerity, providing connection to place. Jones draw on historical research to support this conclusion, and whilst she does not explicitly articulate the link, her analysis seems to have much in common with Weber's notion of disenchantment, where aura and authenticity become powerful and persuasive tools for re-enchanting people in an otherwise detached, rational and progressive world.

What needs further investigation is the link between these qualities of past things (real or perceived), the experiences they engender (in the field, museum or heritage site), and alternate forms of religiosity. This paper posits that the need for authenticity may be a way of expressing religious longing in a secular world, where certain archaeological materials have a particular draw upon people, such that the past replaces notions of an otherwordly or spiritual realm. Hence, the encounter with heritage and museums can - in some contexts, and for some groups or individuals - provide religious experiences in a post-secular way. Duncan $(1995,7-8)$ has already described museums as transformative religious spaces in the modern world: sites that can be compared to temples, but are situated in a secular environment. Partridge (2004), in The Reenchantment of the West, explores how new spiritual practices have appeared and changed the content of traditional religions. What needs to be explored further is to what extent heritage has also played a part in practices of post-secular religion, not only for Neo-pagans but also for seemingly secular people.

\section{Heritage as deep-time phenomen}

Despite the usefulness of this synergy between authenticity and enchantment, Fowler and Harris $(2015,128)$ point out that Jones' relational approach does not fully resolve the issue of how such sites or finds can endure over time. There is still something further to be acknowledged here about the material traces of the work of 'deep time'. Fowler and Harris (2015) make use of Barad (2007) to explore the paradox of how archaeological materials - said to come into existence as bundles of relations (for example in the present) - are still perceived and understood as matter that has endured, extending over deep time (a conundrum which touches on the work of Lucas and Olivier discussed above). Their explanation of this enduring character of archaeological objects is that while they can be understood as sets of relations, rather than essences, the process of decipherin these relations is never fully exhaustive: those formations of reality are always in the process of emergence (Fowler and Harris 2015, 135-37). This notion of durability has much in common with Barad's (2007) 'process ontolegy' (see also Fredengren 2015). It has the potential to provide an alternative model to social constructivist understandings of the heritage-making process. It cou ald also offer a new kind of ethical approach to the past and 'na unrection consists of constantly changing and intraacting phenomena that hold a range of possibilities for such intra-action. These phenomena precede their definition: they cannot be seen as separate actors, but otherwise interconnected world, and make such actors come into being. These cuts have both material and immaterial consequences, where materialization processes act back and participate in this making. What is known about the past intra-acts with the processes from the past, where both contribute to what exists in the world and its consequences. However, materiality does not reflect corist original essence, as it is always in different stages of flux. As described archaeological 'matterings' have a material, albeit evolving persistently over time. Barad (2010) uses the term 'space-time-mattering' to describe the materializing aspects of history. This is

not a linear history, as for Barad (240) 'each scene diffracts various temporalities within and across the field of space-time-mattering, whereby scenes 'are reconfigured within, dispersed across, and threaded through each other. For Barad, this diffractive approach means that matterings are never fully mirrored in culture (for example through memory, meaning or narratives), but have the disturbances can diffract and set off in a variety of directions. Diffraction is for Barad (2007) also method where one material is read through another to trace out difference.

If heritage were to be approached as a series of phenomena, rather than as a social construct (see Fredengren 2015, 120), it would be understood as coming into being through unfolding materialization processes and the intra-activity of the world. By applying similar approaches to those discussed in Fowler and Harris (2015), we would then be able to acknowledge enduring material relations over time, moving beyond the presentism in heritage discourse discussed above. Hence, heritage sites would be conceptualized and valued in ways that were less driven by contemporary socio-political, economic or even cultural needs, foregrounding instead connections with archaeological and geological deep time as important effects of such sites and how they contribute with an agential doing that distributes and diffracts over time. It is hoped that in this refocusing of heritage agendas, alternative understandings of ways of being human and more-thanhuman would emerge, from the different material configurations which 'endured' through the making of our relations with the past. For example, crannogs could be understood as phenomena that are brought into being by the interplay between a range of different human and more-thanhuman actors both now and in the past. Situated within a relational reality, heritage processes would be seen as 'cuts' into that fusion of concepts, materials and relations, producing very specific inclusions and exclusions according to contemporary agendas.

This acknowledgement relates to Barad's $(2010,253)$ point that to carry out an agential cut is to bring in issues of ethics and responsibility towards 'mutually constituted excluded others'. In other words, both intra-activity and agential cuts have real material effects, with ethical consequences. For example, there is a danger that crannogs can be fetishised as exemplars of extraordinary preservation, icons of authenticity amongst other heritage sites. This would be to ignore the 'cowork' that has gone on at such sites, between the past and present, nature and culture, as they evolve as seminal indices for local populations of environmental change, seasonal shifts, and threats to aquatic life. To cut out that relationship between matter and meaning (perhaps merely through ignorance of the site's folklore, use by locals and material intra-actions that would bring these into being) would be to make serious failures by making it a mere heritage site of marvel and revelation. Furthermore, Barad $(2010,266)$ argues that ongoing materialisation processes are inherently enmeshed into ethical issues, yet can provide insights into the ongoing, differentiating entanglements of the world. Environmes, affects people and animals living near the lake shore more than people on dry land. To discuss heritage as a materializing phenomenon would acknowledge this double-take on ethics that involves both concepts and materiality. Here, Barad makes interesting use of Derrida's (1994) concept of both concepts and materiality. Here, Barad makes interesting use of Derrida's (1994) concept of Derrida (1994) argues that Marx's theories continue to haunt society in a ghost-like way. Whether his 
political objectives were realized or not, what Marx's critique instilled in society was an awareness of social injustice and a responsibility to create just outcomes, in future worlds. Whilst failing to be fully embraced in the capitalist world this critique is hard to undo, lo the present, which needs to be dealt with in part through historical analysis. This 'hauntioning of Derrida (1994) defined it works by looking back through the past as a ghost-like apparition, whilst remaining conned to hopes about the future (Barad 2010, 266). However, such re-thinkinist remaing injustices in the past. For examp, the 'mattering' of some of the bog bodies leads on to comp over questions that need to be dealt with, about violent religious practices and possible socia injustices. 'Husstory' will need to be dealt with, about violent relgious practices and possible social injustices. 'History' will continue to disturb us through its prest This mal This means that history is always incomplete, that there are redundancies of mattering that can come to us as surprises, for example through archaeological discovery. This is particularly powerful when (as in the above case studles) the quality of his matter itself appears to disrupt the passage of time and defy decay, percolating from the past with a peculiarly intense endurance, emerging and interfering with the present in unexpected, sometimes unsettling ways. In the case of both crannogs and bog bodies, this can amount to material and immaterial hauntings. Hauntologies are important, Barad argues (2010, 260-61), precisely because they point out these disjunctures in time are imbued with hopes for the future. Such 'anticipation' is not merely a waiting for the future, but purposive action towards that future. As Barad puts it, the now is not just now - it is also a bit of 'then' and hopes for the 'what will be'. For Barad $(2010,261)$, the present becomes stretched towards the future, not only through materializing trajectories - the consequences of Hodder's (2012) 'entanglements', populated by material and immaterial ghosts from the past - but also through expectancies of a variety of futures to come. Barad's model reintroduces agential purpose - and thus hope - into this concept of temporality. Whereas heritage as a meaning-making process risks merely replicating the representations and concerns of the present, concealing or smoothing over those areas of the past which do not fit contemporary narratives, if we embrace heritage as onto-ethicoepistemological phenomena, we disturb and disrupt the relationship between past-present-future as a simple linear, unidirectional arrangement. This diffractive approach contradicts the notion of inevitability in history, challenging it with the enchantment arising from engagement with deep time, and may entice reflections and acts of responsibility and justice between generations. The hauntological potential of deep time then has considerable relevance for the environmental humanities - a potential that has yet to be fully embraced even by heritage practitioners. Enchantment and environmental ethicsNeimanis, Åsberg, and Hedrén (2015) have argued that there is a need for environmentalists to challenge the negative way in which change upon the earth is framed. This kind of discourse often creates a sense of frustration, helplessness and even alienation compartmentalizing environmental change away from other issues of concern. This paper has argued the opposite: that the meeting between people and archaeology, both now and in the past, can be characterized as having energizing, haunting and enchanting effects that connect and engage people powerfully with ethics. Archaeological deep-time enchantment could, for example, be understood as those experiences that occur at specific disjunctures in time, when time appears to be 'out of time'. Whether this is perceived culturally as the result of 'authentic' engagement with heritage, or even a kind of secular religious experience, the results of this process hold the possibility of anincreasing role for heritage in the future. As Northcott (2015) argues, people who understand the landscape as sacred in situated ways have a higher propensity to be involved in practices of care. Hence, to ma use of archaol a a narratives which point out that wetlands and rivers were once understood as holy places may work to foster care for this kind of resource, and to discuss how common interests and cares stretch across several senerations. This view is echoed in Haraway's $(2008,41)$ edict to identify attachment sites 'in search for more liveable "other worlds" inside earthly complexity'. Sites, identify attachment sites in search for more liveable "other worlds" inside earthly complexity'.
bodies and exhibitions could point more strongly to networks extending over deep time, which reveal not just the otherworldy-ness of the past but the ways in which the world has been, and thus could be, very different. By paying close attention to those materialities and their relations, archaeology can contribute to autre-mondialisation by investigating other ways of living with the land and waters.

As Smith (2014) also reveals, these transformations happen personally at a deep level, reinforcing what people 'feel and believe'. Such emotional engagement tends to strengthen their socialand political values as well as personal narratives (127-28). Hence, the enchantment effects of archaeology and heritage could, to use Bennett's $(2001,131)$ idea, work to motivate a move from ethical thinking to ethical action, or in Heaney's mor poetic terms, from seing to 'vision', but also to make a move for better futures to come. Whilst the importans, from seeing to ' $v$ sion', but also to make a in more abstract terms, this knd of vision needs to be mediated through curatoral practices of care, acknowledged in site conservation measures and in policy makng. The examples above show how archaeological sites become attachment sites in a material sense, whereby later building layers incorporate older structures, or seemingly natural features interlace and transgress with cultural ones or changing lake levels are indexed by the crannog sites. In Vibrant Matter, Bennett (2010, xixii, 108) argued that ethics can be understood in a process-oriented materialist way. This paper has embraced Bennett's notion that just as culture is acknowledged as a meshwork of a variety of vibrant human and non-human agencies, politics also needs to be understood as a political ecology in which not only humans participate. Such a political ecology consists of a more-than-human collective that gathers around a problem, and there is a need for policy to acknowledge these others within its program of action in which archaeology - and its materials - also take part. This ties in with an ethics of flourishing (Braidotti 2013) that focuses on more-than-human relations and intergenerational commitments to justice and care. It can create an affirmative engagement with the world wher rather than being an ephemeral interest or cultural luxury, heritage and archaeology matter (Fredengren 2015, 120-22). Indeed, the very vibrancy of the preserved leaf or the faces of long-dead bog bodies may be connected to entice visitors to question those apparently common-sense boundaries of 'here:there', 'presence:absence' or 'nature:culture'. What needs to be researched next is the complex ways in which such enchantments can play out: as Burlein and Orr 2012,13) argue, we should not be naive here: we need to review both the alluring seduction of enchantment and where that might take us, alongside its role as a prompt for ethical action. Its very ambivalent power may bring about both benevolent and destructive effects; for example, Olivier $(2011,23)$ alerts us to the use of archaeology by totalitarian regimes and anti-democratic forces. This is where notions of the enchanting power of such sites must be joined with critical reflections on ethics.

\section{Conclusion}

This paper has argued that encounters with archaeological materials can produce a variety of enchantment effects that could entice people to move from ethical thinking to ethical action. However, in order to realize the potentials to engage in issues of environmental ethics and intergenerational care, heritage matters need to be approached differently as they have roles in wider political ecologies and ethical discussions. This would, however, require a modification of how deeptime materializing processes are handled. As suggested here, heritage may be understood as materializing onto-ethico-epistomological phenomena that both human and more-than humans bring into being. However, these deep-time phenomena do not appear in a linearly arranged way, as materialities percolate at different paces and diffract into the contemporary world. Enchantment effects are attested to both in the past and in the present. Such effects can occur when archaeological materials percolates into the present and thereby create what could becalled deeptime hierophanies. The above-discussed examples show that touching materials from the past such as old stones in buildings or nely excavated materials like the leaf from Derragh may give rise to particularly captivating moments of connectivity that interfere with ordinary, everyday life likewise, the experience of being face to face with a dead person (as in the case of bog bodies) produces similar results. Studies of folk foce a n a dead person (as in the case of bog bodles) produces today call asche understood as holy presences in the landscape. It is also sugested that even further back in time, 
ancient discoveries of old objects or marvelously preserved remains might have led to these places being associated with otherworldly presences, which could be accessed through such watery portals, drawing the sacred out into the world of the living. In both the past and the present, deep-time materialization processes enchanted the living, revealing the past-present in the 'now' -a contemporaneity that is both here and there at the same time - forming new grounds of agency. They reveal worlds where time is out of step, exercising a more-than- human agency in the landscape, quite removed from their many human creators' intents.

May such sites continue to haunt us.

\section{Acknowledgements}

This paper is much inspired by the discussions and comments that were generously given when an earlier version was presented at the 2015 seminar series Unexpected Encounters with Deep Time .

References

Barad, K. 2007. Meeting the Universe Halfway: Quantum Physics and the Entanglement of Matter and Meaning. Durham and London: Duke University Press.

Barad, K. 2010. "Quantum Entanglements and Hauntological Relations of Inheritance: Dis/continuities, Space Time Enfoldings, and Justice-to-Come." Derrida Today 3 (2): 240-268.

Bennett, J. 2001. The Enchantment of Modern Life. Attachments, Crossings and Ethics. Princeton: Princeton University Press.

Bennett, J. 2010. Vibrant Matter. A Political Ecology of Things. London: Duke University Press.

Berry, T. 1988. The Dream of the Earth. Berkley: Counterpoint Press.

Bourke, A. 1999. The Burning of Bridget Cleary: A True Story. London: Pimlico.

Braidotti, R. 2013. The Posthuman. Cambridge: Polity.

Burlein, A., and J. Orr. 2012. "Introduction: The Practice of Enchantment: Strange Allures." WSO Women's Studies Quarterly 40 (3-4): 13-23. Enchantment (Fall/Winter 2012).

Byrne, D. 2009. "The Fortress of Rationality: Archaeology and Thai Popular Religion." In Cosmopolitan Archaeologies, edited by L. Meskell, 68-88. Durham: Duke University Press.

Carey, J. 1999. "The Finding of Arthur's Grave: A Story from Clonmacnoise?" In Ildánach Ildírech. A Festschrift for Proinsias Mac Cana, edited by J. Carey, J. T. Koch, and P.-Y. Lambert, 1-14. Andover: Celtic Studies Publications.

Chakrabarty, D. 2009. “The Climate of History: Four Theses." Critical Inquiry 35 (2): 197-222.

Crutzen, P. J., and E. F. Stoermer. 2000. “The 'Anthropocene'." Global Change Newsletter 41: 17.

Derrida, J. 1994. Spectres of Marx: The State of Debt, the Work of Mourning and the New International. New York: Routledge.

Duncan, C. 1995. Civilizing Rituals: Inside Public Art Museums. London: Routledge.
Edgeworth, M. 2014. "Archaeology of the Anthropocene." Journal of Contemporary Archaeology 1 (1): $73-132$.

Eriksen A. 2014. From Antiquities to Heritage: Transformation of Cultural Memory. New York and Oxford: Berghahn

Fowler, C., and O. J. T. Harris. 2015. “Enduring Relations: Exploring a Paradox of New Materialism." Journal of Material Culture 20 (2): 127-148.

Fredengren, C. 2002. Crannogs. A Study of People's Interactions with Lakes, with Particular Reference to Lough Gara in the North West of Ireland. Bray: Wordwell.

Fredengren, C. 2010. "Lough Kinale: The Archaeology of Lake and Lakeshore." In Kinale Monograph Studies of an Irish Lake, edited by C. Fredengren, I. Stuijts, and A. Kilfeather, 129-166. The Discovery Programme. Bray: Wordwell.

Fredengren, C. 2013. "Posthumanism, the Transcorporeal and Biomolecular Archaeology." Current Swedish Archaeology 21: 53-71

Fredengren, C. 2015. “Nature:Cultures:Heritage, Sustainability and Feminist Posthumanism.” Current Swedish Archaeology 23: 109-130.

Fredengren, C. Forthcoming. “Archaeological Posthumanities: Feminist Re-invention of Humanities, Science and Material pasts." In Reinventing the Humanities, edited by R. Braidotti, aJ. Coles, and C. Åsberg, New York: Springer.

Giles, M. 2008. "Seeing Red: The Aesthetics of Martial Objects in the British and Irish Iron Age." In Rethinking Celtic Art, edited by D. Garrow, C. Gosden, and J. D. Hill, 59-77. Oxford: Oxbow.

Giles, M. 2009. "Iron Age Bog Bodies of North-Western Europe: Representing the Dead" Archaeological Dialogues 16 (1): 75-101.

Gwynne, E., ed. 1991 (1913). The Metrical Dindshenchas. Part III. Dublin: Dublin Institute for Advanced Studies.

Haraway, D. 2008. When Species Meet. Minnesota: University of Minnesota Press.

Harrison, R. 2013. Heritage: Critical Approaches. London: Routledge.

Heaney, S. 1999. "The Man and the Bog." In Bog Bodies, Sacred Sites and Wetland Archaeology, edited by B. Coles, J. Coles, and M. Schou Jörgensen, 3-6. WARP Occasional Papers 12. Exeter: Wetland Archaeology Research Project.

Hodder, I. 2012. Entangled. An Archaeology of the Relationships between Humans and Things. Chichester: Wiley- Blackwell.

Holtorf, C. 2005. From Stonehenge to Las Vegas: Archaeology as Popular Culture. Walnut Creek: Altamira Press.

Humpreys, J. 1998. "Investigation after 5,000 Fish Are Found Dead in Coarse Angling Lake." The Irish Times, June 11. http://www.irishtimes.com/news/investigation-after-5-000-fish-are-found-dead-incoarse-anglinglake- 
1.161805

Jones, S. 2010. "Negotiating Authentic Objects and Authentic Selves: Beyond the Deconstruction of Authenticity." Journal of Material Culture 15: 181-203.

Joy, J. 2015. "Things in Process: Biographies of British Iron Age Pits." In Biography of Objects, edite by D. Boschung, P.-A. Kreuz, and T. Kienlin, 125-142. Morphomata Band 31. Paderborn: Wilhelm Flink.

Latour, B. 2013. "Facing Gaia: Six Lectures on the Political Theology of Nature." The Gifford Lectures on Natural Religion. http://www.BrunoLatour.Fr/Sites/Default/Files/Downloads/Gifford-SixLectures 1.Pdf

Lucas, G. 2015. “Archaeology and Contemporaneity.” Archaeological Dialogues 22 (1): 1-15.

McPhee, J. 1981. Basin and Range. New York: Farrar, Straus and Giroux.

Neimanis, A., C. Åsberg, and J. Hedrén. 2015. “Four Problems, Four Directions for Environmental Humanities:Toward Critical Posthumanities for the Anthropocene." Ethics and the Environment 20 (1): 67-97.

Northcott, M. 2015. "Myth, Ritual, and the New Universe Story in the Inner Hebrides." Journal for the Study of Religion, Nature and Culture 9 (2): 192-198.

Olivier, L. 2011. The Dark Abyss of Time. Archaeology and Memory. London: Altamira Press.

Partridge, C. 2004. The Re-enchantment of the West. London: T\&T Clark International.

Portney, P. R., and J. P. Weyant (eds.), 2013. Discounting and Intergenerational Equity. Taylor and Francis. E-book. http://www.tandfebooks.com/action/showBook?

Raftery, J. 1957. “Lake-dwellings in Ireland.” Scientific Service 43: 5-15.

Rose, D. B., T. van Dooren, T. M. Chrulew, S. Cooke, M. Kearnes, and E. Gorman. 2012. "Thinking through the Environment, Unsettling the Humanities." Environmental Humanities 1: 1-5.

Serres, M., and B. Latour. 1995. Conversations on Science, Culture and Time. Ann Arbor: The University of Michigan Press.

Smith, L. J. 2006. Uses of Heritage. Abingdon and New York: Routledge.

Smith, L. J. 2014. "Visitor Emotion, Effect and Registers of Engagement at Museums and Heritage Sites." Conservation Science in Cultural Heritage 14 (2): 125-131.

Solli, B. 2011. "Some Reflections on Heritage and Archaeology in the Anthropocene." Norwegian Archaeological Review 44 (1): 40-54.

Staunton, U. c. 1986. Sliabh Lugha. A Short Outline of an Ancient Area. Boyle: Roscommon Herald.

Staunton, U. c. 1990. Lough Gara. A Historical Triology and Some Lakeland Poems. Boyle: Roscommon Herald.
Steffen, W. W. Broadgate, L. Deutsch, O. Gaffney, and C. Ludwig. 2015. "The Trajectory of the Anthropocene: The Great Acceleration." The Anthropocene Review 2 (1): 81-98.

Stiglitz, J. E. 2013. Selected Works of Joseph E. Stiglitz: Volume II: Information and Economic Analysis: Applications to Capital, Labor, and Product Markets. Oxford: Oxford University Press.

Weber, M. 1989 (1919). "Science as a Vocation. transl. Michael John." In Max Weber's Science as a Vocation, edited by P. Lassman, andlrving Velody, with Herminio Martins, 3-31. London: Unwin Hyman.

White, L. 1967. “The Historical Roots of Our Ecologic Crisis.” Science 155: 1203-1207. 